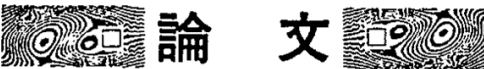

\section{強制振動法による 3 次元角柱に加わる非定常空気力** Unsteady Aeroelastic Forces on a Three Dimensional Model with Square Section}

\author{
谷池 義 人 $^{*}$ \\ Yoshi hi to TANI IKE
}

SUMMARY

The objective of the present paper is to obtain the unsteady aeroelastic forces and the wake flow velocities of a high-rise structure model, i.e., a three dimensional model with square section and to clarify their characteristics. For this purpose, wind tunnel experiments were conducted in smooth flow using the forced oscillation method suggested by Bishop and Hassan. It was so contrived that the experimental instrument would give a harmonic oscillation to the model with a rocking mode in the cross-wind direction.

As the results, the response curves of the aeroelastic cross-wind oscillations with the mass-damping parameter (given in a product of the mass and the damping of structures) were obtained by substituting the unsteady aeroelastic forces for the external force term of the equation of motion, which seem to be great useful for the wind resistant design of the high-rise buildings. A limitation in the applicability of the quasi-steady aeroelastic theory on galloping analysis for the building was also examined.

\section{1. まえがき}

渦励振やギャロッピング等の風向直角方向への 空力不安定現象を考える上で，作用外力である動 的な空気力を知ることは重要である。Parkinson, Novak等）,2) は, ギャロッピング振動時深察の 角柱に作用している゙動的な空気力を，一定の迎角 で静止した角柱に加わる時間平均的な空気力に置
き換觉て，この現象の解明を試みた。しかし，筆 者等 ${ }^{3)}$ の行った実験結果によると,この準定常的 な手法では，角柱の振動に伴なって生じる付加的 な空気力を正確に評価していないために, この理 論による解析結果と振動実験結果とはよく一致し なかった。

渦励振やギャロッピングを含ぬ，風向直角方向

* 京都大学防災研究所助手, 日本建築学会, 日本風工学会

Research Associate, Disaster Prevention Research Institute, Kyoto University Member of AlJ and JAWE.

** 本報は，日本建築学会論文報告集 ${ }^{23)}$ に発表した内容に加筆し，2-30結果を追加したものである。 (本稿受理：昭和 59 年 3 月 8 日，时碚期限：昭和 59 年12月31日) 
への振動時に角柱て作用する動的な空気力を狭い 意味で非定常空気力と呼ぶ。本報では，この空気 力を直接測定できる強制振動装置について概説し, この空気力の特性並びに振動している角柱背後の 非定常な流れの特性を明らかにした。

強制振動装置を用いた非定常空気力の研究は, 最初Fung 及びBi shop. Hassan ${ }^{4)}$ により行われた。 これらはいずれる2次元珄柱の非定常空気力に関 するあのであったが、計測システムが今日ぼ発 達していなかったために，実験精度に多少の疑問 がある。その後, 強制振動装置や測定器等の改良 几伴ない，多くの研究が行われてきた。例党ば， 2 次元円柱飞関して，鉒口・田中 ${ }^{5)}$, 矢野・高原 ${ }^{6}$ 等の研究があり，2次元角柱に関しては，田中・

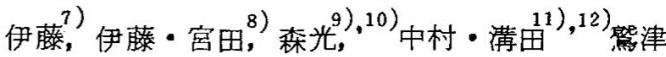
・大筑等 ${ }^{13)}$ の研究があ。

しかし,これら一連の研究は, 断面軸方向に一 様な流れをもつ 2 次元的な構造物に関するすので あるために，これらの結果を 3 次元的な拡がりを もつ建築構造物任直接適用することがでさない。 本研究に颃いては， 3 次元角柱に加わる非定常空 気力を検出できる装置を開発し，これルよって建 築構造物の風向直角方向への振動現象の一部分を 解明した。

\section{2. 実験 概要}

\section{1 強制振動法}

非流線形物体儿作用する非定常空気力を，実験 的に求める代表的な方法に，自由振動法と強制振 動法と呼ばれる2つがある。自由振動法とは，対 象とする物体をバネで弾性支持し，これに適当な 初期変位を与えて気流中で目由振動させ, 振動数 と減衰率とを測定し,これらの值を用いて非定常 空気力を算定する方法である。この方法の長所は 振動装置の製作が簡单な点にあるが, 非定常空気 力を直接測定できないために，定量的に精度のよ い評価を行えない欠点がある。強制振動法とは，
対象とする物体を気流中で強制的に調和振動させ， 物体の慣性力を適当な方法で除去して，非定常空 気力のみを検出する直接的な測定法である。この 方法は，強制振動装置の製作に技術的な難しさが あるが，非定常空気力をより正確に測定できる大 きな利点がある。

本実験では，この空気力の測定に Bi shop $\cdot \mathrm{Ha}$ $\operatorname{ssan}^{4)}$ の提案した強制振動法を用いた。その概要 を以下に述べる。質量と形状が同一の 2 つの角柱 模型を, Fig.2 亿示すよ5に風洞内外に設置し. それぞれを同時に風向直角方向に一定の振幅と振 動数で強制的に振動 (ここではロッキング振動) させる。風洞外の模型をダミーモデルと呼ぶ ${ }^{14)}$ と, 気流中のアクティブモデルの支持点に加わる力に は，求める非定常空気力の他に模型の運動による 慣性力が含まれている。一方，ダミーモデルの支 持点に加わる力は，慣性力のみと見なせるのて， アクティブモデルの支持点の力かららダミ一モデル の力を差し引くと, 求める非定常空気力が得られ る。こ5して得られた非定常空気力は振動時の模 型の慣性力に比べるとかなり小さなるので，次 節に述べる方法で実験の精度を高めることが重要 となる。

\section{2 模型と強制振動実験装置}

この実験精度よく行うには，模型の慣性力を 小さくして，アクティブモデルに加わる非定常空 気力を大きくする工夫が必要である。そのため, 模型を剛性が保てる範囲でできるだけ軽く作り， 模型寸法的空気力が十分得られる大さとした。 Fig.1 飞模型の形状, 寸法, 材質を示す。模型は 断面の辺長比が 1：1の正方形断面角柱とし, 角 柱上面愿さ $2 \mathrm{~mm}$, 底面厚さ $5 \mathrm{~mm}$ のクリル板 で作り，側面には厚さ $3 \mathrm{~m}$ mのバルサ材を用いた。 また，角柱の高さんを幅 るで割って定義したアス ペクト比（ん/b)は，正方形断面をるつ高層ビル の一般的なアスペクト比である 4.5 を用いた。こ の角柱を実験装置に取り付けた状態で固有振動数 

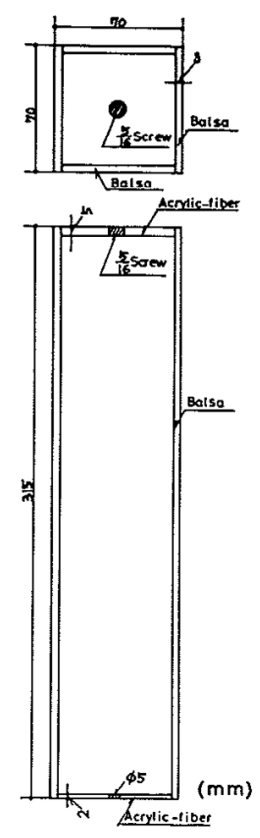

Fig.1 Square prism model.

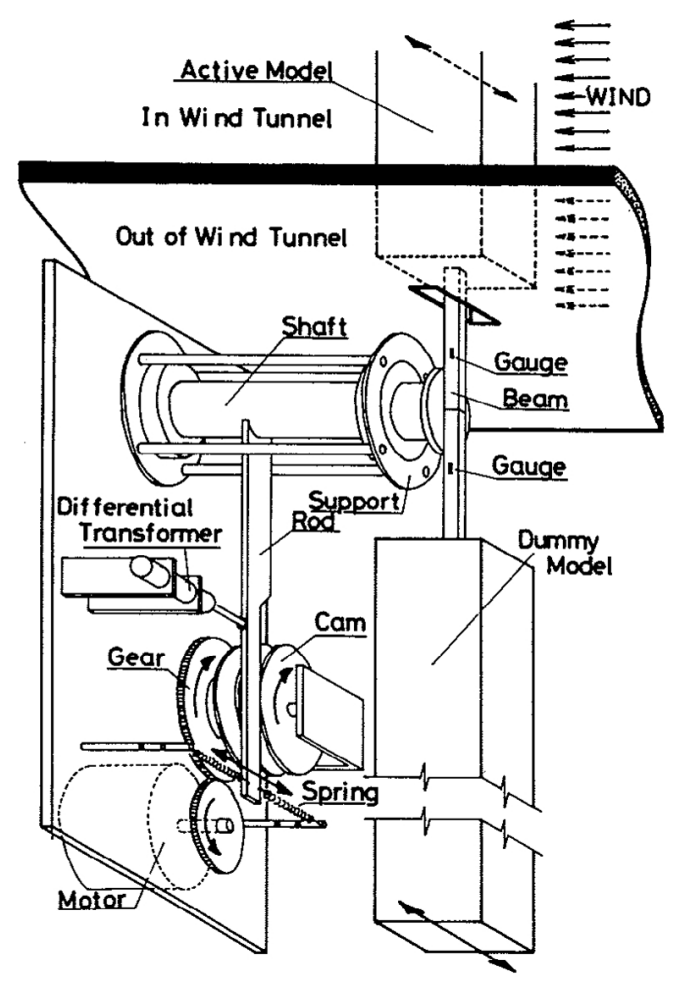

Fig.2 Forced oscillation instrument.
を測定したところ，100Hzであった。

本実験で使用した赛験装置の概略をFig.2 亿示 す。使用したモーターは回転むらの少ない電子直 流モーターで，任意の回転数を設定することがで きる。モーターの回転で歯車軸に取り付けたカム が回転し、このカムの回転運動はロッドに伝って 周期運動になる。ロッドの周期運動は, 回転軸 (シャフト)を介して回転軸の端に取り付けた真 鍮の支持棒(ビーム)へと伝わる。この支持棒に ゲーシを貼り, 両モデルからの出力を引算回路に 入れてアクティブモデルに加わる非定常空気力の みを検出する。なお，角柱の底面とゲーシとの距 離を $60 \mathrm{~mm}$ とする。使用したゲージは半導体形式 のものでありこれれより検出できる歪み量の最 小值は $0.1 \times 10^{-6}$ 程度であった。

振動変位の検出には差動トランスを用いた。振 動振幅の大きさはカムの種類によって異り, 角柱 頂部の水平振幅で $3,6,12 \mathrm{~mm}$ の 3 種類ある。力 ムはいずれす円形であり, 回転軸を円の中心から 少し偏心させた。カムの直径 $(90 \mathrm{~mm})$ 几比べて, 偏心距離（最大で $6 \mathrm{~mm}$ )を小さくしたので，支持 棒に伝わる周期運動を調和振動と見なしても差し 支劣ないと思われる。また，カムとロッドの接触 点には摩擦が生じ，機械的なノイズの発生原因に なる。そのため，ロッド側の接触点付近にべアリ ングを取り付けて摩擦を減らす工夫をした。

\section{3 実験方法}

実験にはゲッチンゲン型の開放風洞を用いた。 強制振動装置に取り付けた 2 つの角柱を測定部の ほ济中央に設置し、ダミーモデルには風があたら ないよ5にカバーで覆った。角柱を取り付ける前 の風洞内の気流の状態は, 高さ方向にはほ様な 風速分布となり，このときの乱れの強さは $0.5 \%$ であった。実験風速 $\mathrm{V} は 1.8 \sim 13 \mathrm{~m} / \mathrm{s}$ 範囲と した。角柱の幅を代表長さにしたときの Reynolds 数は, $\mathrm{R}_{e}=8.6 \times 10^{3} \sim 6.2 \times 10^{4}$ の範囲であっ た。基準風速と角柱後流域の風速変動は, 定温度 
型の熱線風速計を用いて測定した。これらの設置 場所をFig.3 亿示す。な扮, 強制振動実験に先立 ち, 角柱を静止させた状態で変動ローリングモー メントを測定し, Strouhal 数を求めた結果 $\mathrm{S}_{t}=$ 0.115 亿なった。 Strouhal 数から求まる共振風 速 $\overline{\mathrm{V}}_{\text {res }}\left(=1 / \mathrm{S}_{t}=8.7\right)$ 付近の実験風速を密にと り、これから離れるにつれて粗になるようにした。 角柱の強制振動数 $f_{m}$ は $6 \mathrm{~Hz}$ とした。静止空気 中でアクティブモデルとダミーモデルを同時に強 制振動させ, 両者からの出力をアナログ回路に通 して差し引き，その結果が浪济０亿なるようにダ ミーモデルからの出力を調節した。このとき， イズを除去するために $30 \mathrm{~Hz}$ のローパスフィルタ 一を使用した。以上の操作を行った後, 各々の夷 験風速時にアクティブモデルに加わる非定常空気 力, 振動変位, 及び角柱後流域の風速変動をデー
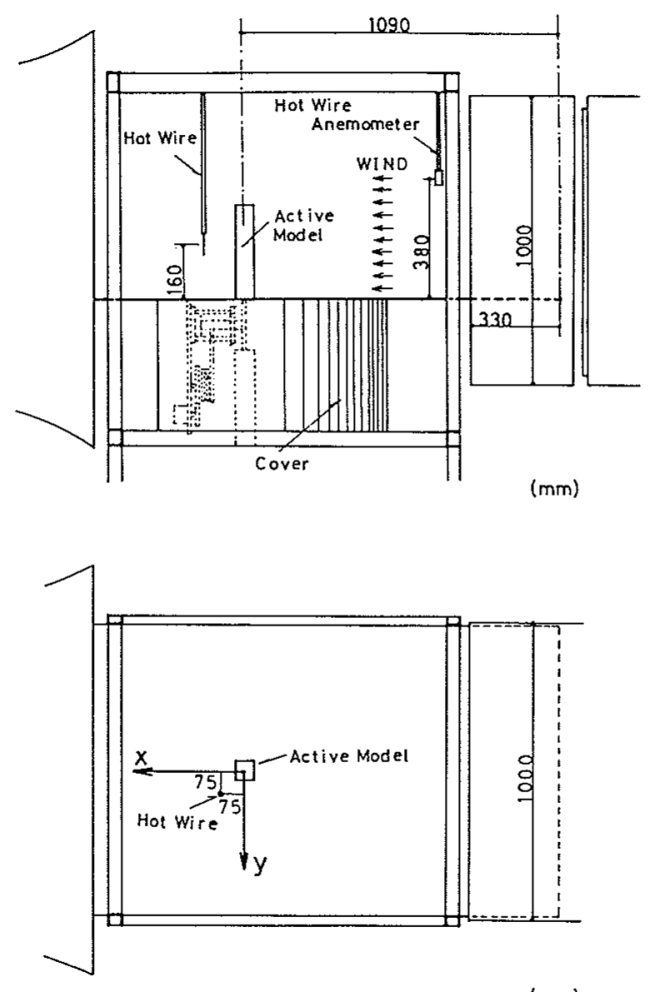

(mm)

Fig.3 Experimental set up in wind tunnel。
タレコーダーに記録した。記録したデータは、シ グナルプロセッサーを用いて解析した。AーD変 換の読み取り間隔は, 非定常空気力のフーリエ展 開, 非定常空気力と変位との位相差, 及び後流域 の風速変動と変位との位相差の場合には $1 \mathrm{~ms} と し$, 非定常空気力のスペクトル解析の場合には $5 \mathrm{~ms}$ とした。解析時間はいずれる8秒間である。な扔， 非定常空気力と変位との位相差を求めるとき似, データレコーダーの変位記録の出力にる $30 \mathrm{~Hz}$ のローパスフィルターをかけて, 両者の相互相関 を計算した。

\section{3. 非定常空気力}

\section{1 非定常空気力の定式化}

実験装置に取り付けた角柱の振動形態は, 風向 直角方向に調和振動する 1 目由度のロッキングと 考党られる。この振動の回転中心は. 支持棒に貼 つたゲーシ位置より $2.5 \mathrm{~cm}$ 下にあるが角柱の回転 半径に比べると小さいから，ここではこの振動の 回転中心を近似的にゲーシ位置とした。

角柱の回転角 $\theta(t)$ は次式となる。

$$
\theta(t)=\theta_{o} \cos 2 \pi f_{m} t
$$

ここで $\theta_{0}$ は小さいので, 角柱頂部の水平振幅 $y_{0}(=3,6,12 \mathrm{~mm})$ 々回転中心 (ゲーシ位置) から角柱頂部までの長さ L $(=375 \mathrm{~mm})$ を用いる と, 次式で表わせる。

$$
\theta_{0} \doteqdot \bar{y}=y_{0} / L
$$

$$
\text { 但し, } \bar{y}=0.008,0.016,0.032 \cdots \cdots \text { (2) }
$$

森光・伊藤 ${ }^{10}$ 等によれば, 角柱がある一定の振幅 で調和振動しているときい作用する非定常空気力 のろちで, この振動て寄与する成分が種々の振幅 に対して得られれば, 角柱の振動性状を定常状態 のみならず，振幅が時間とともに変化する過渡状 態まです求めることができる。ここでは，上に示 した 3 種類の振幅を選び，それぞれの振幅に拈け る非定常空気力を求めて, 3 次元角柱の風向直角 方向への振動状態を調べることにする。 


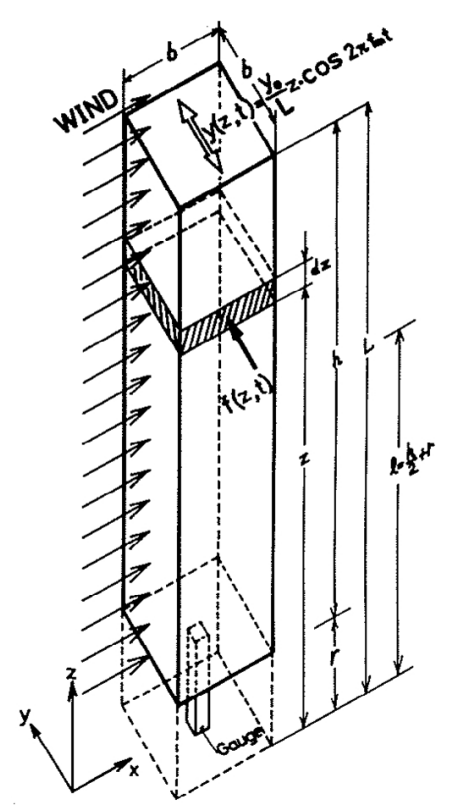

Fig.4 Definition of unsteady aerodynamic force acting on model oscillating transversely.

角柱がロッキング振動をしているときいは，作 用外力である非定常空気力をモーメントで表わす 方が運動方程式を作る上で便利である。Fig.4を 見ると,ゲージの出力はモーメント量となり, 角 柱に加わる空気力の回転中心まわりのモーメント $\mathrm{Q}(t)$ 飞相当する。

$$
\mathrm{Q}(t)=\int_{r}^{\mathrm{L}} f(z, t) \mathrm{z} \cdot d \mathrm{z}
$$

ここで, $f(z, t)$ は $z$ 点に作用する単位長さあた りの非定常空気力（ここでは揚力）を示し，rは 角柱底面とダーシとの距離で $r=6 \mathrm{~cm}$ である。

非定常空気力 ( 正確には非定常ローリングモー メント) $\mathrm{Q}(t) は$ は般に時間的に不規則となる ので確率統計的な処理が必要になる。 $\mathrm{Q}(t)$ 飞含 まれる成分のうち, 振動数 $f_{m}$ の調和振動飞寄与 するのは $f_{m}$ と同じ振動数成分である。このため, ここでは $f_{m}$ と同じ周波数成分 $\mathrm{Q}_{m}(t)$ をフーリ エ展開の原理により求めた。

$$
\begin{aligned}
\mathrm{Q}_{m}(t) & =\left|\mathrm{Q}_{\mathrm{L}}\right| \cos \left(2 \pi f_{m} t+\beta_{\mathrm{Q}}\right)=\mathrm{Q}_{\mathrm{R}} \cos 2 \pi f_{m} t \\
& -\mathrm{Q}_{\mathrm{I}} \sin 2 \pi f_{m} t \quad \cdots \cdots \cdots \cdots \cdots(4)
\end{aligned}
$$

ここで

$$
\begin{aligned}
& \mathrm{Q}_{\mathrm{R}}=\frac{1}{\mathrm{~T}} \int_{-\mathrm{T}}^{\mathrm{T}} \mathrm{Q}(t) \cos 2 \pi f_{m} t \cdot d t \\
& \mathrm{Q}_{\mathrm{I}}=\frac{-1}{\mathrm{~T}} \int_{-\mathrm{T}}^{\mathrm{T}} \mathrm{Q}(t) \sin 2 \pi f_{m} t \cdot d t \\
& \left|\mathrm{Q}_{\mathrm{L}}\right|=\sqrt{\mathrm{Q}_{\mathrm{R}}^{2}+\mathrm{Q}_{\mathrm{I}}^{2}}, \mathrm{Q}_{\mathrm{R}}=\left|\mathrm{Q}_{\mathrm{L}}\right| \cos \beta_{\mathrm{Q}}, \\
& \beta_{\mathrm{Q}}=\tan ^{-1}\left(\mathrm{Q}_{\mathrm{I}} / \mathrm{Q}_{\mathrm{R}}\right)
\end{aligned}
$$

である。また， Tは解析時間でここでは 8 秒とす る。 $\beta_{Q}$ はフーリエ展開後の $Q_{m}(t)$ と変位との位 相差を示し， $\beta_{Q}>0 の と き Q_{m}(t)$ は変位に対し て位相の進みをつ。(1)，(2)式を用いて(4)式を書 きな拉すと次式になる。

$$
\mathrm{Q}_{m}(t)=\mathrm{Q}_{\mathrm{R}} \frac{\theta(t)}{\bar{y}}+\frac{\mathrm{Q}_{\mathrm{I}}}{2 \pi f_{m} \bar{y}} \theta \cdot(t) .
$$

したがって， $Q_{R}$ は変位と同相の成分， $Q_{I}$ は速度 と同相の成分となる。 $\mathrm{Q}_{\mathrm{R}}, \mathrm{Q}_{\mathrm{I}}$ が求まると， $\mathrm{Q}_{m}$ $(t)$ の特性をとらえることができる。

さらに，ここで $\mathrm{Q}_{\mathrm{R}}, \mathrm{Q}_{\mathrm{I}},\left|\mathrm{Q}_{\mathrm{L}}\right|$ 及びQ( $(t)$ の 2 乗 平均平方根 $\sqrt{\overline{\mathrm{Q}(t)^{2}}}$ を無次元化し, 次の空気力 係数を導入する。

$$
\begin{aligned}
& \mathrm{C}_{\mathrm{R}}=\mathrm{Q}_{\mathrm{R}} / \frac{1}{2} \rho \mathrm{V}^{2} b h \ell, \mathrm{C}_{\mathrm{I}}=\mathrm{Q}_{\mathrm{I}} / \frac{1}{2} \rho \mathrm{V}^{2} b h \ell \\
& \left|\mathrm{C}_{\mathrm{L}}\right|=\sqrt{\mathrm{C}_{\mathrm{R}}^{2}+\mathrm{C}_{\mathrm{I}}^{2}} \quad \cdots \cdots \cdots \cdot(9) \\
& \mathrm{C}_{\mathrm{rms}}=\sqrt{\mathrm{Q}(t)^{2}} / \frac{1}{2} \rho \mathrm{V}^{2} \text { bh } \quad \cdots \cdots \cdots \cdots \cdot(10)
\end{aligned}
$$

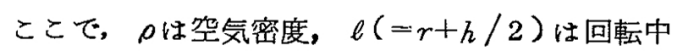
心から角柱の高さの半分までの距離である。なお, $\mathrm{Q}(t)$ 及び $\mathrm{Q}_{m}(t)$ は, 角柱の代表面積 $b \times h$, 代 表回転半径 $\mathrm{L}$ ( あるいは $\ell$ ), 振幅 $y_{o}$, 振動数 $f_{m}$, 基準風速 $\mathrm{V}$, 及び空気密度 $\rho$ 飞依存すると考兄ら れることから、これらの空気力を(9)〜(11)式のよう 几表わせば, 各々の空気力係数䛔，それぞれ独立 な 2 つの無次元量 $\overline{\mathrm{V}}\left(=\mathrm{V} / f_{m} b\right)$ と $\bar{y}\left(=y_{0} / \mathrm{L}\right)$ の関数になる。）ここで 
と呼ばれる。

\section{2 角柱後流域の風速変動}

振動する角柱後流域の風速変動 $v(t)$ を. 前節々 同様の手法で解析し, 角柱の振動数と同じ成分 $v_{m}(t)$ を求め, さらに $v_{m}(t)$ と変位 $\theta(t)$ との位 相差 $\beta_{v}$ 計算した。

$$
\begin{aligned}
v_{m}(t)= & \left|v_{\mathrm{L}}\right| \cos \left(2 \pi f_{m} t+\beta_{v}\right)=v_{\mathrm{R}} \cos 2 \pi f_{m} t \\
& -v_{\mathrm{I}} \sin 2 \pi f_{m} t
\end{aligned}
$$$$
\text { ここで } \quad v_{\mathrm{R}}=\frac{1}{\mathrm{~T}} \int_{-\mathrm{T}}^{\mathrm{T}} v(t) \cos 2 \pi f_{m} t \cdot d t,
$$

$$
v_{I}=\frac{-1}{\mathrm{~T}} \int_{-\mathrm{T}}^{\mathrm{T}} v(t) \sin 2 \pi f_{m} t \cdot d t
$$$$
\left|v_{L}\right|=\sqrt{v_{R}^{2}+v_{I}^{2}}
$$$$
\beta_{v}=\tan ^{-1}\left(v_{\mathrm{I}} / v_{\mathrm{R}}\right)
$$

$v_{\mathrm{R}}$ は恋位と同相の風速変動成分， $v_{\mathrm{I}}$ は速度と 同相の風速変動成分を示す。但し， $\bar{V} か ゙$ 共振風速 $\overline{\mathrm{V}}_{\mathrm{res}}$ を越えて高くなると， $v_{\mathrm{R}}$ と $v_{\mathrm{I}}$ の絶対値が相 対的に小さくなるために， $\beta_{v}$ の計算精度が悪く

\section{$\bar{V}=7.5$}

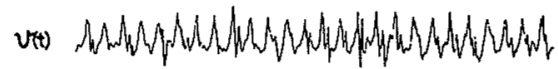

Q(t) MWWWWWWWWWWWW

Q $*$ NWWWWWWWWWWWWW

$$
\overline{\mathrm{V}}=14.1
$$

$v(t)$

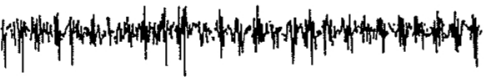

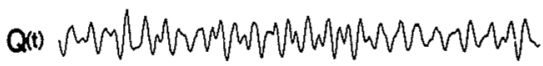

$\theta(*)$ WWWWWWWWWWWWW

Fig.5 Time records of wake velocities, unsteady aerodynamic forces and displacements。
なる。また，前節で述べた理由より， $\beta_{v}$ は $\beta_{Q}$ と 同様, 無次元風速 $\overline{\mathrm{V}}$ と無次元変位 $\bar{y}$ の関数々考光 られる。

な报, Fig. 5 kv $(t), \mathrm{Q}(t)$ 及び $\theta(t)$ の波形 を示す。図の上段は共振風速 $\overline{\mathrm{V}}_{\text {res }}(=8.7)$ 付近の $\overline{\mathrm{V}}=7.5$ のときの波形、下段は $\overline{\mathrm{V}}_{\text {res }}$ 越えた $\overline{\mathrm{V}}=$ 14.1 のときの波形を示し，いすれる波形の大き さは任意である。

\section{4. 実験結果}

4.1 振動速度と同相の空気力係数 $\mathrm{C}_{I}$

(9)式の $C_{I}$ は,角柱の振動速度と同相の成分であ るから振動系の減衰に関係する。 $\mathrm{C}_{\mathrm{I}}$ が正のとき 空気力は振動系に対して負の仕事をし，負のとき 正の仕事をする。C 効果が振動系の減衰を上まわつたとき，振動系全 体の減衰力は負となり，振動は大きくなる。空力 負減衰効果と振動采の減衰とが等しいとき, 振動 は一定の振幅になる。また, 空力負減衰効果が振 動采の減衰より小さい場合でも $C_{I}$ が正であると， 振動系全体の减衰力は小さくなり, 何らかの外乱, 例完ば風の乱れや急激な風向変動などによって振 動が増大ずるおそれがある。

$\mathrm{C}_{\mathrm{I}}$ の結果をFig.6亿示す。図中の○、口, $\triangle$ 印は，それぞれ $\bar{y}=0.032,0.016,0.0080 を き$ の $\mathrm{C}_{I}$ の値である(他の節に扣いても同じ記号を用 いる)。横軸に無次元風速 $\bar{V}$, 縦軸飞 $\mathrm{C}_{I}$ をとり, 横軸上の 印は共振風速 $\bar{V}$ res $(=8.7)$ を示す。 な技, 図中の実線は線形の準定常理論による空気 力係数を示す。これについては後の 5 章で述べる。 $\overline{\mathrm{V}}_{\mathrm{res}}$ 付近に招いて， $\mathrm{C}_{\mathrm{I}}$ の符号は負から正に反転 する。その反転点は， yが大きくなるてつれ高 風速側に移行する。正に反転した後， $C_{I}$ は極値を 示しその後単調に減少する。 3 種類の矛から判断 すると， $C_{I}$ の極值はある振幅以上になると増加し ないようである。つまり，振動の発達に寄与する 空気力は, 振幅に比例して大きくならない。また, 


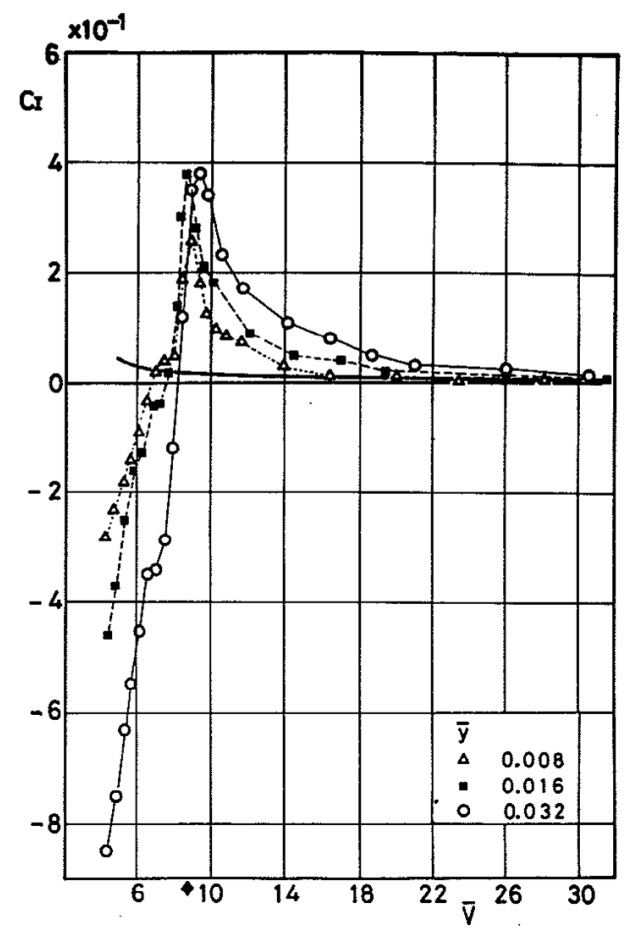

Fig.6 Unsteady aerodynamic force coefficient $C_{I}$ compared with $C_{I}^{*}$ calculated by linear quasi-steady theory of galloping.

$\bar{V}_{\text {res }}$ 付近の $C_{\mathrm{I}}$ は $\bar{V}$ の増加につれて大きくならな い。これらのことから $\bar{V}_{\text {res }}$ 付近で生じる渦励振 は， $C_{I}$ が正となり自励振動的な傾向をもつが, $\bar{y}$ そ $\overline{\mathrm{V}}$ 関して非線形になることから，この振動の 特徵ともい壳るピーク応答を示すのであるう。

$\overline{\mathrm{V}}$ が 20 を越えると， $C_{I}$ は $\overline{\mathrm{V}}$ の増加につれて 徐々に減少し，ある一定值に近つくくまた， $\bar{V} か ゙$

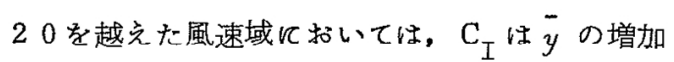
につれて大きくなり, 自励振動(ここではギャロ ッピング)が生じるときの一般的な傾向を示す。 なお，2次元角柱の場合飞は，振動モード及び無 次元振幅の定義が夷験と異るためと，両者の $\mathrm{C}_{\mathrm{I}}$ を 直接比較することはできないが，グラフの傾向は よく似たものになる。

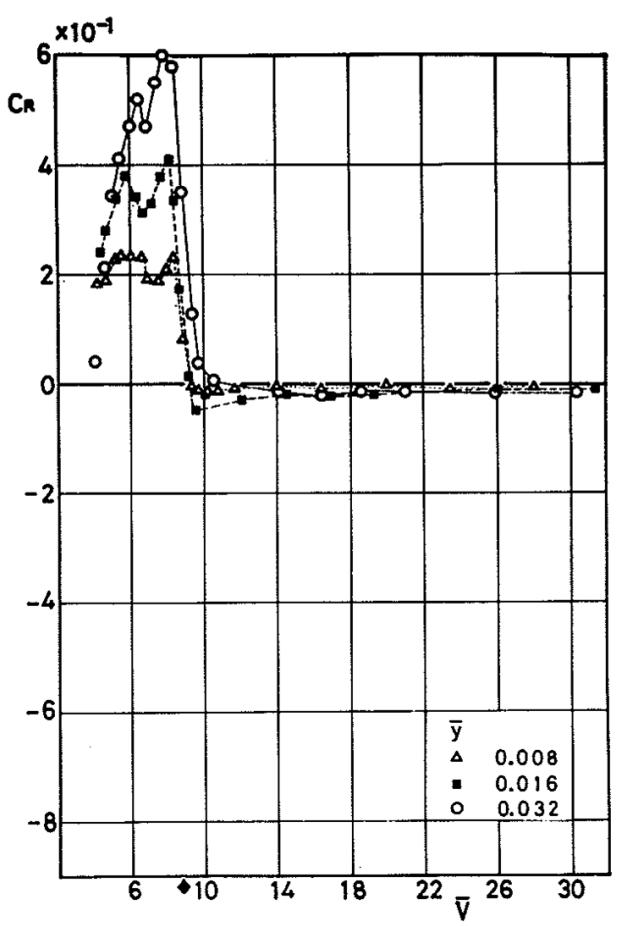

Fig.7 Unsteady aerodynamic force coefficient $C_{R}$ versus reduced wind velocity $\bar{V}$.

4.2 振動変位々同相の空気力係数 $\mathrm{C}_{\mathrm{R}}$

$\mathrm{C}_{\mathrm{R}}$ は角柱の振動変位と同相の成分であるから， 振動系のバネ定数に関係する。 $\mathrm{C}_{\mathrm{R}}$ が正のとき,空 気力は振動系の剛性を弱め振動数を低くするよう 几㗢き, 負のときれは振動亲の剛性を強め振動数 を高くするように㗢く。

$\mathrm{C}_{\mathrm{R}}$ の結果をFig.7 亿示す。 $\mathrm{C}_{\mathrm{R}}$ のグラフの傾向 は全体的飞 $C_{I}$ とよく似ている。 $\overline{\mathrm{V}}$ が6から8 付 近で $C_{R}$ はつの極值をつっ一つはV $\bar{V}_{\text {res }}$ 付近 でもら一つは的 res 以下で見られる。 $\overline{\mathrm{V}}_{\text {res }}$ 以下 で見られる極值は，可の堌加につれてV̄res て近 つくようである。伊藤・宮田 ${ }^{8)}$ の求めた 2 次元角 柱の $\mathrm{C}_{\mathrm{R}}$ においても,同じ傾向が見られる。V̄res

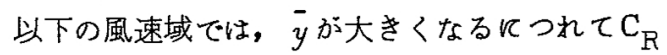


も大きくなる。したがって，角柱の振動数を低下 するように空気力が作用するがこの大きさは角 柱の復元力に比べると高々 $10 \%$ 程度である。そ のため，振動数の変化はほとんど生じないものと 思われる。実際， 7 章で調べた自由振動実験に㧍 いても，振動数の変化はほとんど見られなかった。

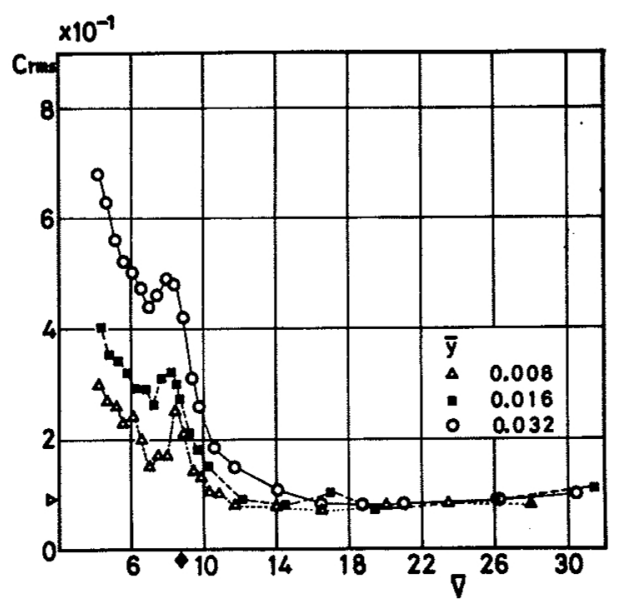

Fig.8 Unsteady aerodynamic force coefficient $\mathrm{Crms}$ versus reduced wind velocity $\overline{\mathrm{V}}$.

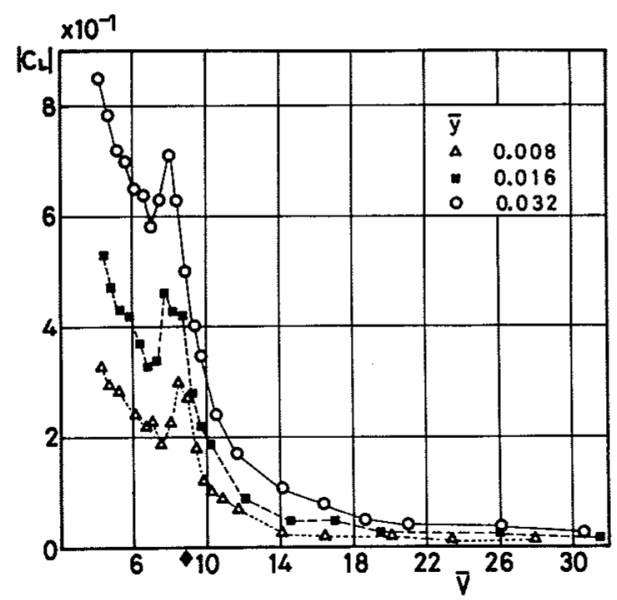

Fig.9 Unsteady aerodynamic force coefficient $\left|C_{L}\right|$ versus reduced wind velocity $\overline{\mathrm{V}}$.
4.3 非定常空気力の振幅と 2 乗平均平方根

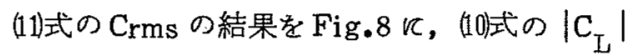
の結果をFig.9 飞示す。Fig.8の縦軸のD印は, 静止角柱に作用する変動ローリングモーメントの 2 乗平均平方根を, $\frac{1}{2} \rho \mathrm{V}^{2} b h \ell$ で割って無次元 化したものである。

Crms, $\left|\mathrm{C}_{\mathrm{L}}\right|$ | $\overline{\mathrm{V}}_{\mathrm{res}}$ 付近で極值を示す。極值 付近は角柱の振動数 $f_{m}$ と渦の発生周波数 $f_{s}$ と が一致する同期領域に相当するが,この領域で $\mathrm{C}_{\mathrm{rms}}$ は $\left|\mathrm{C}_{\mathrm{L}}\right|$ より小さくなる。これは非定常空 気力 $Q(t)$ の振幅のばらつきが小さくなることに 対応し,この空気力が周期 $1 / f_{m}$ の正弦波に近く なっていることを意味する。事実，Fig.5 亿示し $た \mathrm{Q}(t)$ の波形を見ると, 同期領域内にある $\overline{\mathrm{V}}=$ 7.5 のときにはほほ正弦波に近く,その振動数も $f_{m}$ に等しくなる。極值付近の非定常空気力には, 渦 (ここでは角柱静止時に発生するStrouhal 数 成分の渦 ）ょる強制力と, 角柱の振動飞ともな 5 付加的な空気力 (この力も角柱の振動飞ともな って発生する渦による強制力と考克られる)とが 同周期，同位相で加わっているものと思われる。 また, この極值領域を示す風速幅は $\bar{y}$ の增加につ れて拡がる傾向にある。この領域より $\overline{\mathrm{V}}$ が低くな ると, 振動飞とるなう付加的な空気力が卓越し, Strouhal 数成分の瀜による強制力は小さくなる ものと思われる。このことは，6 章に示す非定常 空気力のスペクトル解析からも明らかになる。

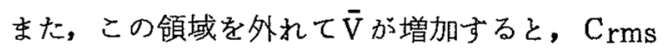
は可の大されかかわらず一定值に近づく。この 值は，静止角柱飞作用する変動ローリングモーメ ントから求めた值（縦軸のD印）飞ほ潘しい。 このことは, 角柱の振動にともなら付加的な空気 カの $\mathrm{C}_{\mathrm{rms}}$ への寄与が小さくなることを意味する。 つまり, 角柱静止時に発生するStrouhal 数成分 の渦による強制力の寄与が大きくなることを示す。 なお， $\bar{y}$ が小さくなるにつれてより低い可で一定 值に近づくようである。これとよく似た現象が, 
角柱振動時の側面の平均压分布にも見られる。 これらの現象は，6章に示すように可の大きさに よる同期領域の拡がりと関係づけられる。

4.4 非定常空気力と変位との位相差, 及び風 速変動と変位との位相差

(7)式の $\beta_{Q}$, 及び(12)式の $\beta_{v}$ の結果を Fig.1 0 と Fig.1 1 亿示す。いずれる横軸に $\bar{V}$, 縦軸に位相

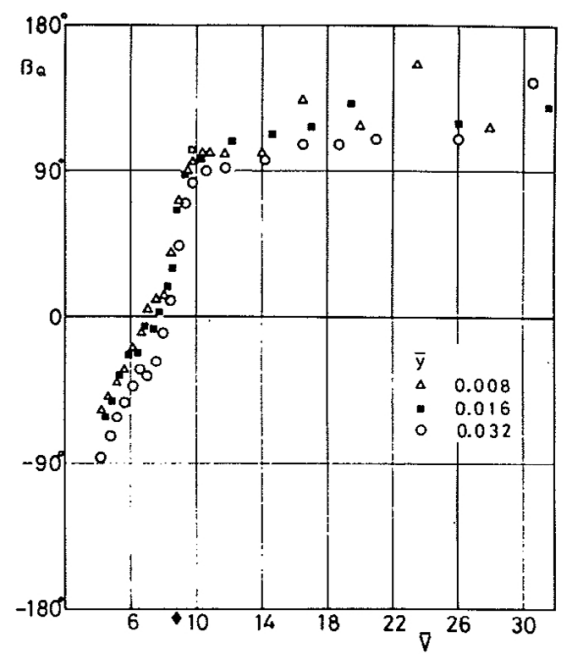

Fig.10 Phase angle $\beta_{Q}$ versus reduced wind velocity $\overline{\mathrm{V}}$.

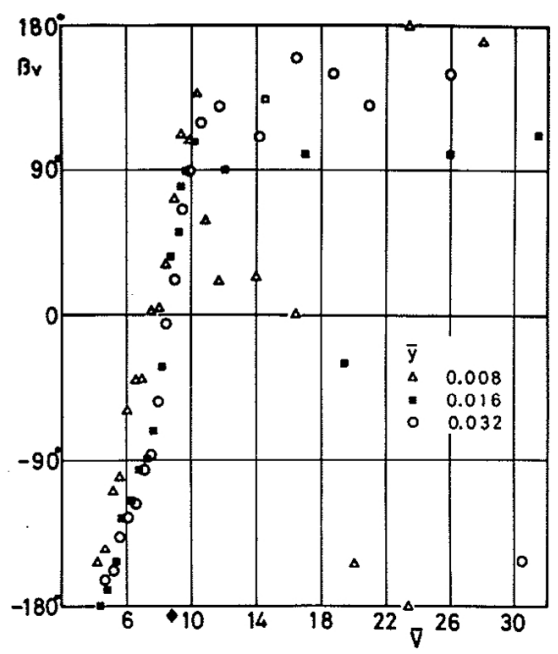

Fig.11 Phase angle $\beta_{v}$ versus reduced wind velocity $\overline{\mathrm{V}}$.
差（度)をとる。墜はV 変化し, $90^{\circ}$ 前後の值をとる。符号の反転点は, $\mathrm{C}_{\mathrm{I}}$ の場合々同様 $\bar{y}$ の増加につれて高風側に移る。 この負から正への位相の変化が, $C_{I}$ の值を負から 正に移行させる要因になっている。

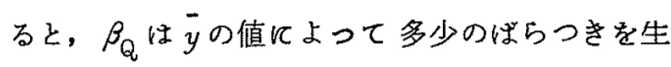
じ，100〜140 の值をとる。2 次元角柱を用 いた実験に扔いてる， $\beta_{Q}$ はV resを少し越えたと こるで負から正へと変化する。正江変化した後の $\beta_{Q}$ は, 研究者 $\left.{ }^{8}, 10\right), 13$ 汇よって若干異り $40^{\circ} \sim$ $90^{\circ}$ の值になる。

$\beta_{v}$ す $\bar{V}_{\text {res }}$ 付近では $\beta_{Q}$ と同様の傾向を示し, 負から正への変化を示す。このことから， V̄res 付近では, 角柱後流域の風速変動が振動子の上う を働きをして, 非定常空気力に何らかの影響を及

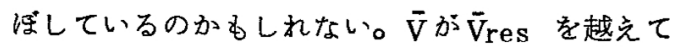
増加すると，解析上の精度の低下により $\beta_{v}$ の一 般的な性状を見い出すととは困難になるが， $\bar{y}=$ $0.008,0.032$ のときの $\beta_{v}$ は $180^{\circ}$ あいい一 $180^{\circ}$ 凡近づくようである。中村・溝田 ${ }^{12)}$ によ ると， 2 次元角柱の $\beta_{v}$ は高風速域において角柱 の振動変位と问相になり， $0^{\circ}$ 又は $180^{\circ}$ になる。

\section{5. 線形の準定常理論による空気力係数 $\mathrm{C}_{\mathrm{I}}{ }^{*}$}

ギャロッピングの解析に用いられる線形の準定 常理論によると，Fig.4 亿示す単位長さあたりの 空気力 $f(z, t)$ は次のよう飞表わされる。

$$
\begin{aligned}
& f(z, t)=-\mathrm{C}_{\mathrm{F}}(z, t) \cdot \frac{1}{2} \rho \mathrm{V}^{2} b \\
& \mathrm{C}_{\mathrm{F}}=\frac{\mathrm{A}_{1}}{\mathrm{~V}} \frac{\partial y(z, t)}{\partial t}, \mathrm{~A}_{1}=\left(\frac{\partial \mathrm{C}_{\mathrm{L}}}{\partial \alpha}+\mathrm{C}_{\mathrm{D}}\right) \cdots(14) \\
& \alpha=0 .
\end{aligned}
$$

ここで, $\mathrm{C}_{\mathrm{L}}$ は揚力係数, $\mathrm{C}_{\mathrm{D}}$ は抗力係数, $\alpha$ は迎 角を示す。 $z$ 点の水平変位 $y(z, t)$ は，(1)，(2) 式より $y(z, t)=z \theta(t)$ となるので，(14)式は(15)式 で表わせる。

$$
\mathrm{C}_{\mathrm{F}}(z, t)=\frac{\mathrm{A}_{1}}{\mathrm{~V}} z \dot{\theta}(t)
$$


(13)，(15)式を用いると，非定常空気力Q $(t)$ を次式 で表わすことができる。

$$
\begin{aligned}
& \mathrm{Q}(t)=\int_{r}^{\mathrm{L}} f(z, t) z \cdot d z \\
& =\frac{-\mathrm{A}_{1}}{\mathrm{~V}} \cdot \frac{1}{2} \rho \mathrm{V}^{2} b \int_{r}^{\mathrm{L}} z^{2} d z \cdot \dot{\theta}(t) \cdots \cdots \cdots \cdots \cdot(16)
\end{aligned}
$$

線形の準定常理論を用いると, $\mathrm{Q}(t) 飞 は \dot{\theta}(t)$ の成分のみがあらわれ， $\theta(t)$ の成分は見られな い。つまり， $\beta_{Q}$ が $90^{\circ}$ になるのである。したが って, (16)式と(8)式の $\dot{\theta}(t)$ の係数を等しいと置く ことにより, 線形の準定常理論による空気力係数

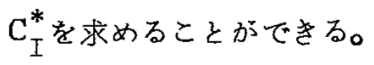

$$
\begin{aligned}
& -\frac{\mathrm{A}_{1}}{\mathrm{~V}} \cdot \frac{1}{2} \rho \mathrm{V}^{2} b \int_{r}^{\mathrm{L}} z^{2} \cdot d z=\frac{1}{2} \rho \mathrm{V}^{2} b h \ell \mathrm{C}_{\mathrm{I}}^{*} / \\
& 2 \pi f_{m} \bar{y} \quad \overline{\mathrm{V}}=\mathrm{V} / f_{m} b \text { 用いて } \\
& \mathrm{C}_{\mathrm{I}}^{*}=\frac{-2 \pi \mathrm{A}_{1} \bar{y} \int_{r}^{\mathrm{L}} z^{2} \cdot d z}{b h \ell} \cdot \frac{1}{\overline{\mathrm{V}}} \cdots \cdots \cdots \cdots \cdot(\mathrm{l})
\end{aligned}
$$

C $\mathrm{C}_{\mathrm{I}}^{*}$ の結果をFig.6の太線で示す。ここでうう值は 最も大きい 0.032 とし， $\mathrm{A}_{1}$ の值仕参考文献(22)上 りー0.23とした。

○印で示した $\mathrm{C}_{\mathrm{I}}$ と $\mathrm{C}_{\mathrm{I}}^{*}$ とは, $\overline{\mathrm{V}} か ゙ 30$ 前後の高 風速域で比較的よく一致するが，このときの $\beta_{Q}$ 《Fig.10より約 $130^{\circ}$ になり, 準定常理論の成 立する $90^{\circ}$ にはならない。また, $\overline{\mathrm{V}}_{\mathrm{res}}$ 付近で, $\mathrm{C}_{I}^{*}$ はC $C_{I}$ に比べてかなり小くなっている。この理 論では角柱の振動にとあなって発生する付加的な 空気力を考慮していないために，実際作用して いる架気力を過少に評価しているるのと思われる。

これらの結果から, 線形の準定常理論は, $\overline{\mathrm{V} て ゙ ~}$ 30 以上の高風速域にならないと適用できないる のと思われる。このことは, 以前筆者等 ${ }^{3)}$ の行っ た準定常理論による応答曲線と振動実験值との比 較に扣いて， $\overline{\mathrm{V}}$ 換算して $\overline{\mathrm{V}}=25 \sim 35$ の風速 域にならないと，両者の精度のよい一致が見られ なかったことからも明らかである。，2次元角柱の 場合には、この理論の適用できる風速は研究者に
よって異り，大筑・热津等 ${ }^{33)} の \bar{V}>14$ とする説 と, 中村・溝田 ${ }^{12)} の \bar{V}>20 \sim 30$ とする説とが ある。いずれにせよ，この理論の適用風速は，3

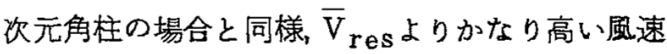
域になる。

\section{6. 同期領域}

非定常空気力 $Q(t)$ の主要成分を調べるために, スペクトル解析を行った。Fig.1 2 亿結果の一例 ( $\bar{y}$ の最も小さい0.008のとき)を示す。A－D 変換の読み取り間隔を $5 \mathrm{~ms}$ とし, 周波数領域での 分解能を $0.39 \mathrm{~Hz}$ とした。図の横軸は周波数 $(\mathrm{Hz})$, 縦軸は個々のパワー $\mathrm{S}(f)$ を $25 \mathrm{~Hz}$ をでの全パワ ー $\overline{\sigma^{2}}$ で割って無次元化した值（\%)を示す。また， 図中の数字は $\bar{y}-f_{m}-\overline{\mathrm{V}}$ の值を示し, $\mathrm{m}, \mathrm{s}$ は それぞれ振動数成分，Strouhal 数成分を示す。

図から明らかなように，非定常空気力の主な成 分は角柱の振動数成分 $\left(f_{m}\right.$ 成分) $)$, 角柱静止時 飞発生する渦の周波数成分 $\left(f_{s}\right.$ 成分) の 2 つであ る。 $\overline{\mathrm{V}}$ が $\overline{\mathrm{V}}_{\mathrm{res}}(=8.7)$ 上り低い風速域では $f_{m}$ 成 分のパワーが卓越し, $\overline{\mathrm{V}}$ res 付近は $f_{m}$ 成分のパワ 一のみが見られ，さらにVが高くなると逆に $f_{s}$ 成分のパワーが卓越してくる。つまり, 低風速域 では角柱の振動によって生じる付加的な空気力が 非定常空気力の大半を占めるのに対し, 高風速域 では逆に角柱静止時に発生するStrouhal 数成分 の渦に上る強制力が支配的になる。また， $\overline{\mathrm{V}}_{\text {res }}$ 付近では， $f_{m}$ 成分のパワーと $f_{s}$ 成分のバワーが 一体になる、いわゆる同期現象加確認できた。

次に，このスペクトル解析をさらに細かい風速 幅で行い, 得られたスペクトルをもとにして，そ の主要成分である $f_{m}$ 成分と $f_{s}$ 成分の周波数の比 $f_{s} / f_{m}$ と $\overline{\mathrm{V}}$ との関係を求めた。Fig.1 3 の上列飞 $\bar{y}=0.008$, 中列 $\bar{y}=0.016$, 下列 $\kappa \bar{y}=0.032$ のときの結果を示し, いずれる横軸に $\overline{\mathrm{V}}$, 縦軸に $f_{s} / f_{m}$ の値をとる。

一般飞角柱のStrouhal 数は, 風速の高低,すな わちReynolds 数の大小にかかわらずほば定にな 

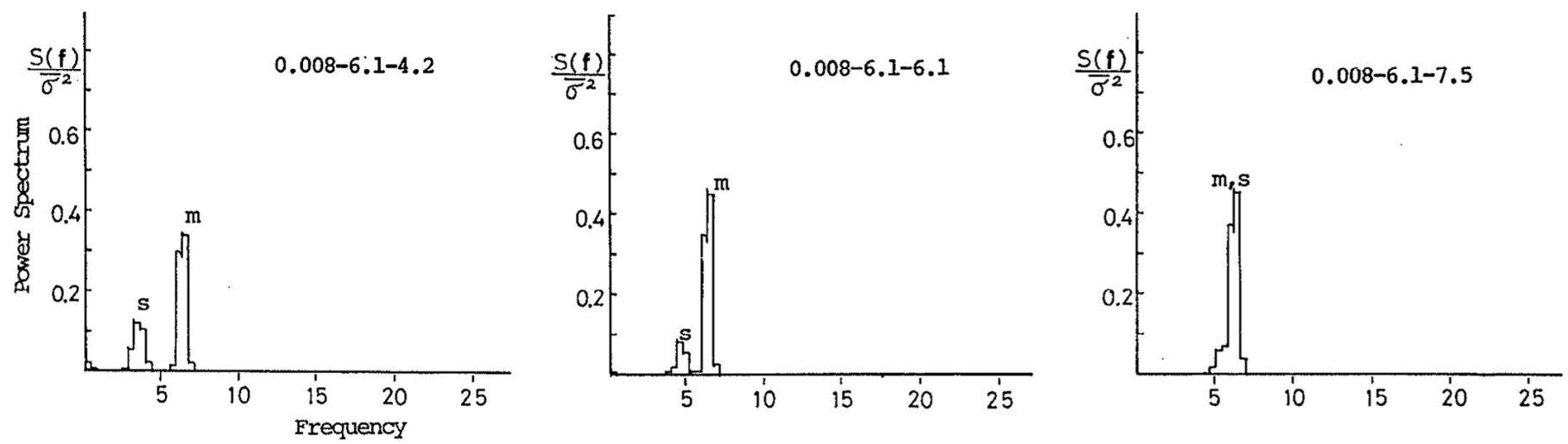

$\frac{1}{1}$
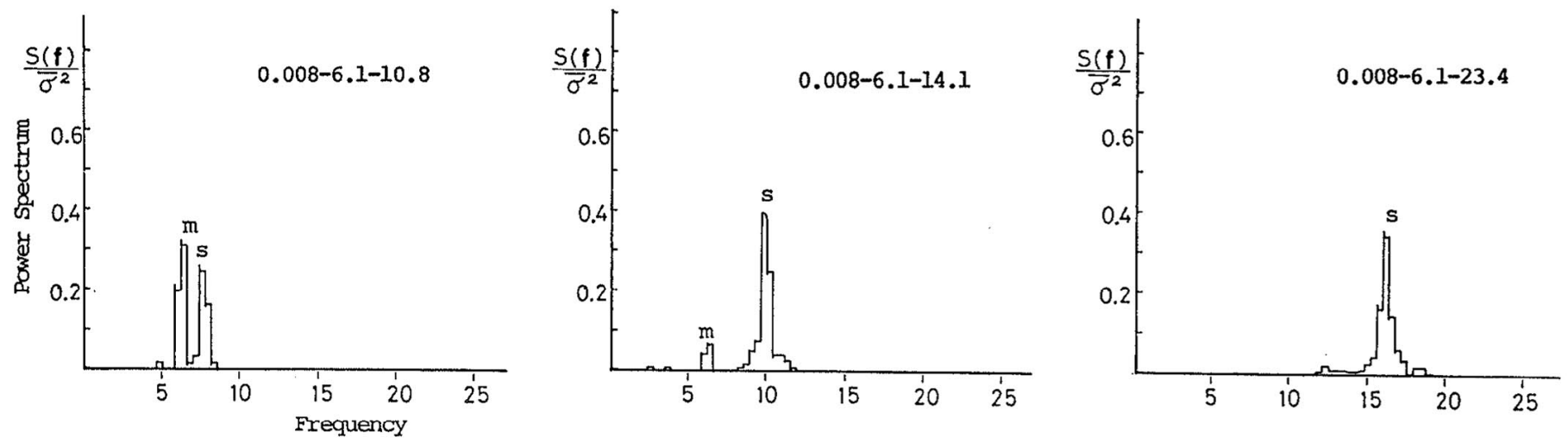

Fig. 12 Nondimensional power spectra of

unsteady aerodynamic forces $(\bar{y}=0.008)$. 


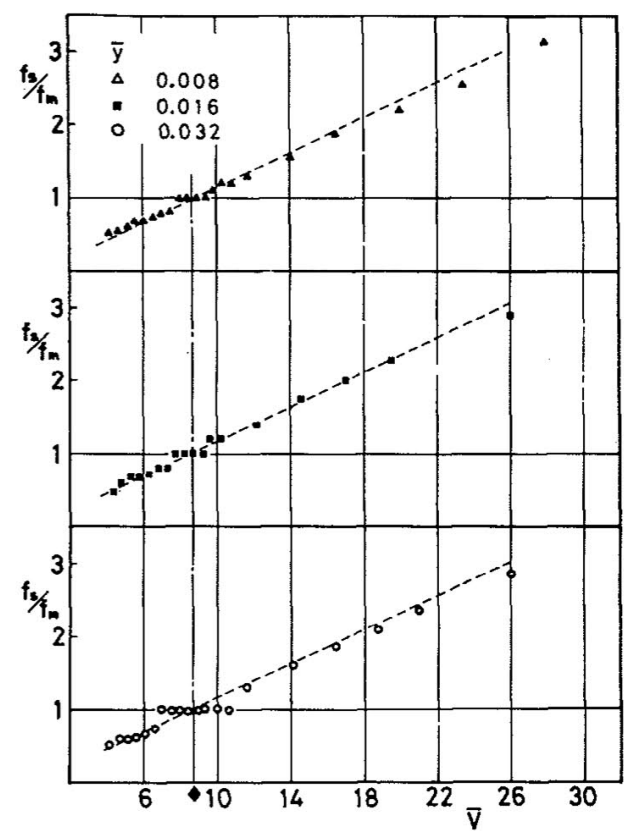

Fig.13 Oscillation-vortex shedding frequency ratios versus reduced wind velocities.

ると言われている。したがって, 角柱静止時に発 生する渦，いわゆるStrouha1 数成分の渦の発生 周波数 $f_{s}$ は風速江比例すると見なされ，次の(18) 式で表わされる。

$$
f_{s}=\frac{s_{t} \mathrm{~V}}{b}
$$

(18)式を無次元風速 $\overline{\mathrm{V}}\left(=\mathrm{V} / f_{m} b\right)$ を用いて表わす 々,

$$
\frac{f_{s}}{f_{m}}=\mathrm{S}_{t} \overline{\mathrm{V}}
$$

になる。この関係をFig.13の図中に破線で表わ す。この破線は，( $\left.\overline{\mathrm{V}}, f_{s} / f_{m}\right)=\left(\overline{\mathrm{V}}_{\mathrm{res}}, 1\right)$ を通り， $\mathrm{S}_{t}(=0.115)$ の勾配をるつ直線になる。

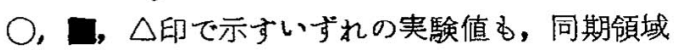
付近を除き，この直線上にのっている。このこと から, 角柱の振動時にもStrouhal 数成分の渦が 発生し，その周波数は角柱静止時の場合々同様風
速（ここでは無次元風速）飞比例することがわか る。同様の傾向が 2 次元内柱を用いたParkinson ${ }^{16)}$ Tanida ${ }^{17)}$ Hartlen Currie ${ }^{18)}$ 等の実験結果, あ るいは 2 次元角柱を用いた大築・㨶津 ${ }^{13)}$ の実験結 果にる見られる。 $f_{m}=f_{s}$ となる同期領域は、 $\overline{\mathrm{V}}_{\text {res }}$ を中心とした風速域に見られ，その風速幅はyの 增加につれて拡がるようである。また，その風速 域の両端を見ると，非同期領域から同期領域及び 同期領域から非同期領域への移行は急激である。

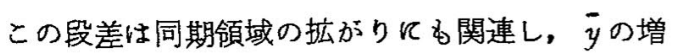
加につれてその段差も大きくなる。

\section{7. 風向直角方向の自由振動実験} 強制振動法による実験結果を検討するために， 自由振動実験との比較を行った。その概要は次の そおりである。自由振動実験装置は, 角柱が風向 直角方向人自由に回転できるよ5弾性支持されて 扣り，その振動妿位は板バネに取り付けだ゙ージ により検出できる仕組みになつている。自由振動 実験では角柱の減衰定数 $\mu 2.5 \times 10^{-3}$ とし, 実験風速を段階的に上げながらそのときの振動応 答を調べた。角柱の振動は, 各々の風速に対して 一定の振幅と振動数をるつ定常振動になるために， 振動系の減衰力と空力負減衰力の大きさは等しく なる。このときの結果をFig.14の○印で示す。

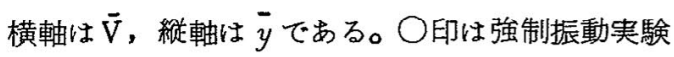
により得られた応答曲線である。すなわち, 強制 振動実験汇より求まる空力負減衰力と, 自由振動 実験に括ける角柱の減衰力とが等しくなるときの $\bar{y}$ z $\bar{V}$ Fig.6のC I のグラフからプロットしたも のである。この応答曲線の求め方の詳細について は次章を参照されたい。また，図中の斜線部は前 章で求めた同期領域の拡がりを示す。

自由振動実験氏よる応答曲線と, 強制振動実験 による応答曲線とを比較したところ，両者の結果 はよく一致した。自由振動実験では減衰定数 $\mu$ が 小さいために，渦励振とギャロッピングとは分離 


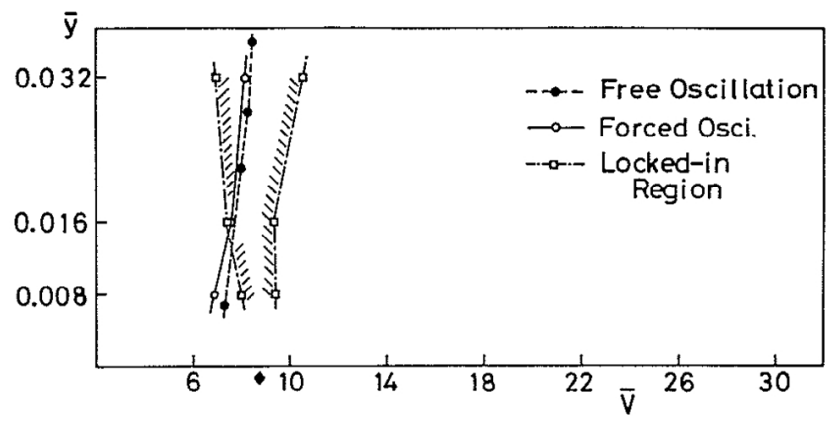

Fig.14 Response curve obtained by forced oscillation technique and its comparison with free oscillation expriment.

せず， $\overline{\mathrm{V}}_{\mathrm{res}}$ 付近で生じた瀜励振がそのままギャ口 ッピングル移行したるのと思われる。 $\bar{y} か ゙ 0.008$ より小さいときのC $C_{\mathrm{I}}$ の測定結果がないので詳し いことはわからないが，自由振動実駼から推定す ると, $\overline{\mathrm{V}}_{\text {res }}$ 付近の振動は $\bar{y} か ゙ 0.016$ 以上になる と同期領域内に入り，この領域内では Strouhal 数成分の渦による強制力が作用するので強制的な

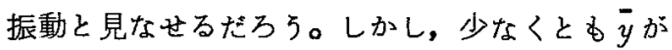
0.008 から 0.016 の範囲内での振動は，また同 期領域内に入っていないとと, 及び $C_{I}$ の值が正 であることにより，振動にともなって生じる空力 負減衰効果飞るとつく自励的な振動 るであろう。

\section{8. 非定常空気力から求めた応答曲線}

\section{1 リミットサイクル}

角柱の運動方程式と 4.1 節で求めた $C_{I}$ を用いて, 振動の生じる不安定領域が角柱の力学的特性によ

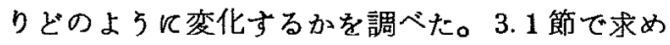
た非定常空気力 $Q_{m}(t)$ を外力としたときの角柱の 運動方程式は次のようになる。

$$
\begin{array}{r}
\int_{0}^{\mathrm{I}} m(z) z^{2} d z \cdot \ddot{\theta}(t)+\mathrm{C} \dot{\theta}(t)+\mathrm{K} \theta(t)=\mathrm{Q}_{\mathrm{R}} \cos \\
2 \pi f_{m} t-\mathrm{Q}_{\mathrm{I}} \sin 2 \pi f_{m} t
\end{array}
$$

但し, $\int_{0}^{\mathrm{L}} m(z) z^{2} \cdot d z(=\mathrm{I}$ と拓く) 性角柱の慣性モ
ーメント，Cは減衰係数，Kは回転剛性を示ず。 ここで(20)式を複素数表示し,さらに(9)式の係数を 用いると次のようになる。

$$
\begin{gathered}
\mathrm{I}\left\{\ddot{\theta}(t)+2 \mu \omega \dot{\theta}(t)+\omega^{2} \theta(t)\right\}=\frac{1}{2} \rho \mathrm{V}^{2} b h b \times \\
\left(\mathrm{C}_{\mathrm{R}}+i \mathrm{C}_{\mathrm{I}}\right) e^{i 2 \pi f_{m} t} \ldots \ldots \cdots \cdots \cdots \cdots \cdot(21) \\
\text { ここで, } i=\sqrt{-1}, \omega=2 \pi f_{0}=\sqrt{\mathrm{K} / \mathrm{I}}, \\
\mu=\mathrm{C} / 2 \mathrm{I} \omega \quad \succeq \jmath_{0}<。
\end{gathered}
$$

(21)式の解を

$$
\theta(t)=\bar{y} \cdot e^{i 2 \pi f_{m} t}
$$

と括く。(22)式を(21)式に代入し，さ5反 $\overline{\mathrm{V}}=\mathrm{V} / f_{m} b$ の関係を用いると, 次の連立方程式が得られる。

$$
\left\{\begin{array}{c}
4 \pi^{2} \mathrm{I} \bar{y}\left\{\left(\frac{f_{O}}{f_{m}}\right)-1\right\}=\frac{1}{2} \rho b^{3} h \ell \overline{\mathrm{V}}^{2} \cdot \mathrm{C}_{\mathrm{R}}(\bar{y}, \overline{\mathrm{V}}) \\
\cdots \cdots \cdots(23 . \mathrm{a}) \\
8 \pi^{2} \mathrm{I} \mu \bar{y} \frac{f_{O}}{f_{m}}=\frac{1}{2} \rho b^{3} h \ell \overline{\mathrm{V}}^{2} \cdot \mathrm{C}_{\mathrm{I}}(\bar{y}, \overline{\mathrm{V}}) \\
\cdots \cdots \cdots(23 \cdot \mathrm{b})
\end{array}\right.
$$

したがって， $\bar{V}$ と角柱の形状及び力学的特性が与 光られると， $\mathrm{C}_{\mathrm{R}}, \mathrm{C}_{\mathrm{I}}$ のグラフを用いて(23)式を解く ことができる。 $\bar{y} と f_{m}$ が求まると(2试の解が決 定できる。

ところで, 実際の建築構造物の風による振動を 考兑た場合, その振動数は風速の高低にかかわら ずほぼ定になり,かつ構造物の固有振動数 $f_{0}$ に 等しくなる。この現象は 7 章の自由振動実験結果 においてる見られ，角柱の振動数 $f_{m}$ はV(あるい 
はV $\bar{V}$ )の高低にかかわらず $f_{m}=f_{o}$ になる。した かっって $f_{m}$ は既知となり角柱の応答曲線を求める 際には, ( $23 . b)$ 式のみを用いればよい。こ の式を整理し，角柱の振動が定常，あるいは增大 するときの条件を求めると次式になる。

$$
\begin{gathered}
\mathrm{C}_{\mathrm{I}} \geq \frac{16 \pi^{2} \mathrm{I} \mu}{\rho b^{3} h \ell} \cdot \bar{y} \cdot \frac{1}{\overline{\mathrm{V}}^{2}} \cdot \cdots \cdots \cdots \cdots \cdots \cdots(24) \\
\text { ここで } \delta=\frac{16 \pi^{2} \mathrm{I} \mu}{\rho b^{3} h \ell} \quad \cdots \cdots \cdots \cdots \cdots \cdots \cdots \cdots(25)
\end{gathered}
$$

とおいて，ठを質量減衰パラメーターと定義する。 Scruton ${ }^{20)}$ Kよると,構造物が固有振動数で振動 するときには，相似のパラメーターとして，構造 物と空気の密度比と減衰定数么をそれぞれ独立に

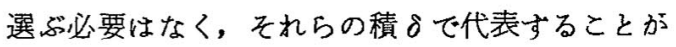
できる。このことは上で示した運動方程式の展開 からも明らかである。

さて，ここで(24)式を用いて振動応答のリミット サイクルを求めてみよ5。まず，角柱の諸性質か $5 \delta$ が定まる。この $\delta を(24)$ 式右辺に代入し, 右 辺全体の值とFig.6 几示した $C_{I}(\bar{y}, \bar{V})$ の值との 大きさを比べることにより，振動が定常になると きの $\bar{y}$ その関係，すなわちリミットサイクルが 求まる。但し， $\mathrm{C}_{\mathrm{I}}$ の值を読み取るとき, 類しかないので中間の值に関しては直線補間して 求めた。

Fig.15 比質量減衰パラメーターの值を $\delta=0$, $300,600,1200,2400$ と怙いたときのリミ ットサイクルである。図中の斜線は $\delta=600$, 12000 と文不安定領域(振動が発生する領域)

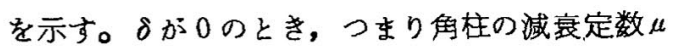
が理論上0になるときでる, 空力負減衰振動の発

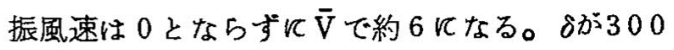

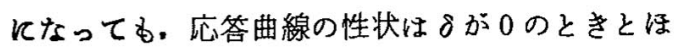
とんど変りがなく、いずれも渦励振からの発振が そのまま゙ャロッピングに移行している。また，

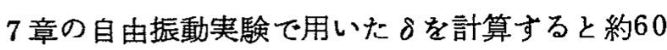

になるので, Fig.1 4 の○印の応答曲線は $\delta=60$ のときのあのである。

$\delta$ か 600 のとき 2 つの不安定領域に分離す る。一つは渦励振, も5一つはギャロッピングと

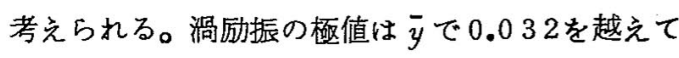
おり，通常の建築物に怙いては主体構造の崩壊に つながる。森光等 ${ }^{9), 10)}$ は Poincare の orbital stability ${ }^{21)}$ 次関する定理を用いて，2 次元角柱 の振動応答の安定性を検討している。ここでは, この方法を応用して求めた不安定なリミットサイ ク 几 $^{23)}$ 図中比破線で示す。不安定なリミットサ イクルとは， $\overline{\mathrm{V}}$ がある值のとき一定の振幅 $y$ で振 動している角柱に微小な外乱を与えた場合に，そ の後の振動が発散めるいは収束し, 元の振幅に戻

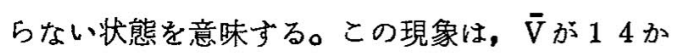
ら18の範囲で見られるが, 2 次元角柱の場合に はその発生領域は $\bar{V} て ゙ 10$ 前後と低くなる。

$\delta$ が1200のときには, $\overline{\mathrm{V}}_{\text {res }}$ 付近で瀜励振の

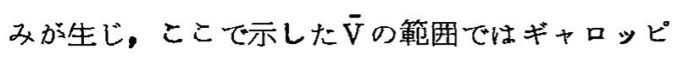
ングが生じない。 $\delta$ が大なり， $\delta=2400 \mathrm{~K}$ なると， $\overline{\mathrm{V}}_{\mathrm{res}}$ 付近で渦励振の発生する不安定領 域が狭くなる。さらによが大きくなると，不安定 領域は存在しなくなるものと思われる。そのよう な場合, 角柱は固有振動数で振動せず， Strouhal 数成分の渦の発生にとるなう振動数で振動する。 しかしながら,この場合の振幅は固有振動数で振 動する場合の振幅に比べて，十分に小さくなり耐 風設計上無視しても差し支えないであろう。

8.2 振動の発生領域と質量減衰パラメーター との関係

Fig.15をるとにて, 渦励振やキャャロッピン

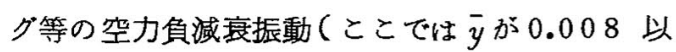
上になる振動を対象にした)の発生する風速域が， 質量減衰パラメーター 変化するかを調べた。Fig.16亿との結果を実線

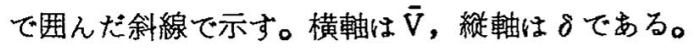
但し, 振動の発生する風速域に不安定なリミット 


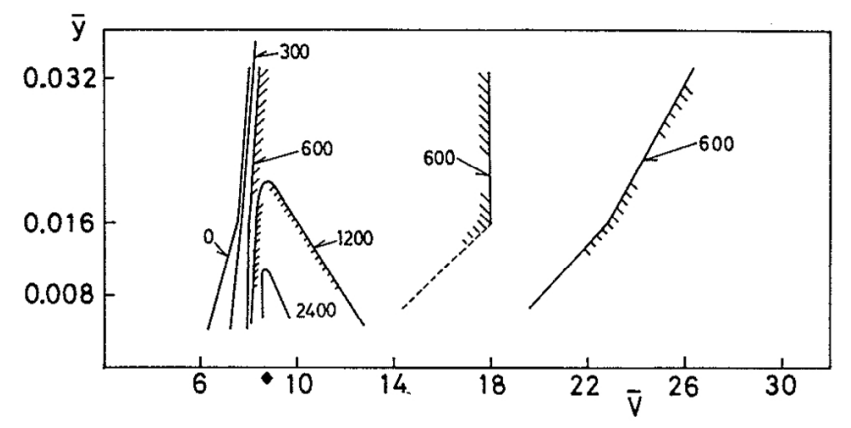

Fig.15 Variations of response curves with mass-damping parameters.

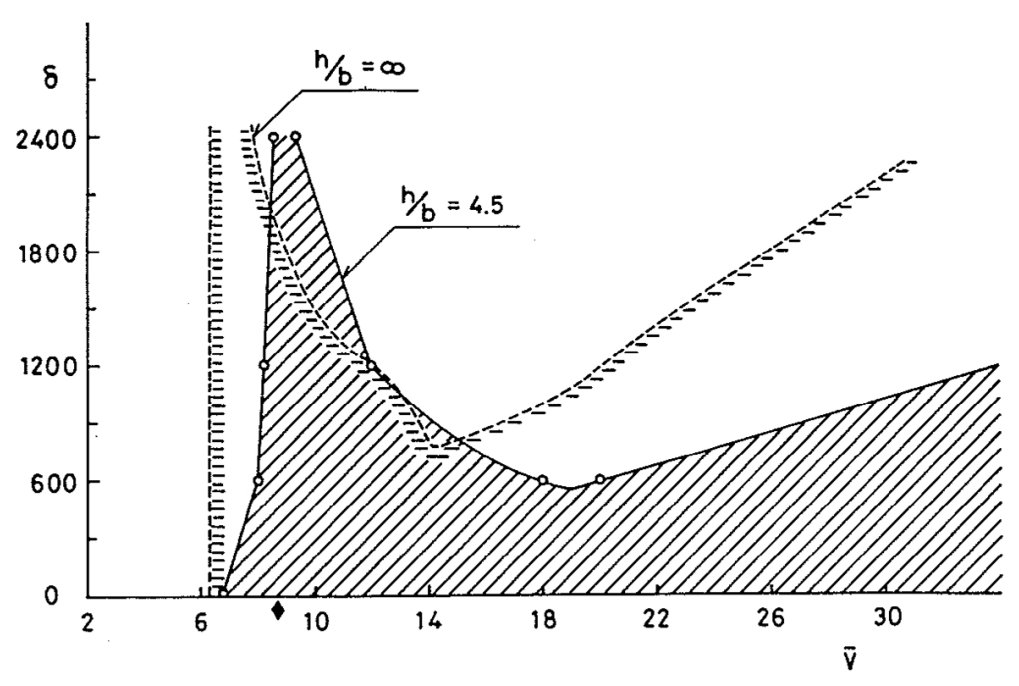

Fig.16 Regions of aerodynamic instabilities varied with mass-damping parameters.

サイクルがあるときには、リミットサイクルが安 定になる風速域まで振動の発生領域を拡げた。例 えはFig.15 亿示す $\bar{y}=0.008$ と $\delta=600$ のミ ットサイクルの交点は, $\overline{\mathrm{V}}=8$ と $\overline{\mathrm{V}}=15$ のつ あるが $\bar{V}=15$ は不安定なりミットサイクル上に あるので,リミットサイクルが安定になる $\bar{V}=18$ の風速域にまで振動の発生領域を拡げ, これを一 方の限界とした。また, 図中の破線 $(h / b=\infty)$ は, Scruton ${ }^{20)}$ の求めた 2 次元角柱の $\bar{V}-\delta$ の関 係である。但し, 振幅 $a_{0} / b$ （ $a_{0}$ は並進運動の 振幅）は 0.01 以上である。2 次元角柱の質量減
衰パラメーター* $\delta^{\prime}$ は, $\delta^{\prime}=\frac{4 \pi m \mu}{\rho b^{2}}(\mathrm{~m}$ は単 位長さあたりの質量)で定義されているために， このままでは本実験と比較できない。そこで， 3 次元角柱の $m$ と $\mu$ が高さ方向比一定であると仮定 ᄂ,

$$
\delta=\frac{8}{3} \pi \frac{h}{b} \delta^{\prime}
$$

の関係導いた。したがって, 図中のScruton ${ }^{20)}$ の結果は, $\overline{\mathrm{V}}-\delta^{\prime}$ の関係を(26)式を用いて, $\overline{\mathrm{V}}-$ ঠの関係になおしたものである。

$\delta$ が 600 上り小さいときには，振動の発生領

*1983 年の国際風工学会議に拝いて, この值はScruton 数と呼ばれることになった。 
域は 2 次元角柱と 3 次元角柱とでほとんど差がな く，いすれも $\overline{\mathrm{V}} \geq 6 \sim 7$ になる。 $\delta$ が 60 以上上 になると, 振動の発生領域は $\bar{V}_{\text {res }}$ 付近と $\bar{V}_{\text {res }}$ よ り高い風速域の 2 つに分れる。前者は渦励振, 後 者はギャロッピングによるすのと考六られるが、 これらの領域はいずれる 3 次元角柱の方が 2 次元 角柱に比べて上り高風速側にずれている。この発 生領域のずれは $\delta$ の増加につれて大きくなる。し たがって, 3 次元角柱は 2 次元角柱に比べて空力

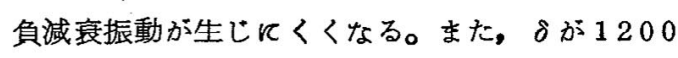
以上㣙を， 3 次元角柱のギャロッピングの発

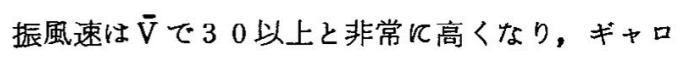
ッピンクは生じルくくなる。

\section{9. むすび}

無次元風速 $\overline{\mathrm{V}}$ がある範囲内の一様流中に扣いて, 3 次元の正方形断面角柱儿作用する非定常空気力 の特性を明らかにすることができた。その結果， ギャロッピンクの解析に用いられる準定常理論は, $\overline{\mathrm{V}} 3$ が 以上にならないと適用できないるのと思 われる。

渦励振やギャロッビングなどの空力負減衰振動 の応答曲線が，角柱の質量(ここでは慣性モーメ ントI）と減衰定数 $\mu$ の積からなる質量減衰パラ メーター $\delta\left(=16 \pi^{2} \mathrm{I} \mu / \rho b^{3} h \ell\right)$ によどのよう 几変化するかを求めた。この結果, 実際の直方体

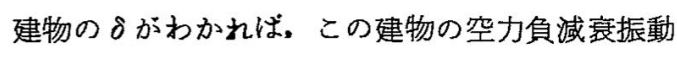
の発振風速及びその掁幅の大きさを予測すること ができ，今後の酎風設計に役立つものと思われる。 空力負隇衰振動の発生する風速域は, $\delta か ゙ 600$ 未満のとき《は 2 次元角柱と 3 次元角柱とでほと

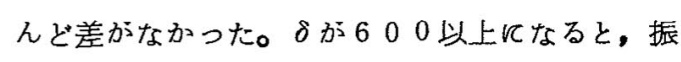
動の発生領域は共振風速 $\overline{\mathrm{V}}$ res 付近と,それより高 い風速域の 2 つ分充た。前者は渦励振，後者は ギャロッピングによるすのと考えられるがここれら の領域はいずれも 3 次元角柱の方が 2 次元角柱氏 比べて上り高風速側にずれることがわかった。さ
らに $\delta か ゙ 1200$ 以上飞なると， 3 次元角柱のギャ

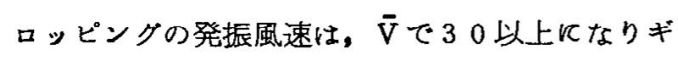
ヤロッビングは生じにくくなることがわかった。

\section{謝辞}

本報をまとめるに際し，数多くの御教示と有益 な助言を与えて頂さました京都大学防災研究所石 崎潑雄教授に感謝の意を表します。ぬた，変動空 気力の測定方法に数々の御教示を頂きました同研 究所桂順治助教授，実験装置の較作々風洞赛験 $儿$ 協力を得ました羽野浮介技官と杉政和光技官. 並 びに実験及び解析に多大の協力を得た東畑設計事 務所の中山久司君に感謝の意を表する。

\section{参考文献}

1) Parkinson, G.V.: Aeroelastic galloping in one degree of freedom. Proc. Int.Conf. on Wind Effects on Buildings and Structures (Teddington), 1963,pp.581-609.

2) Novak, M.;Galloping oscillations of prismatic structures, Proc. ASCE, Vol. 98, EM1, Feb.,1972,pp.27-46.

3）石崎灙雄・谷池義人・近藤宏二：風に上る角 柱の振動不安定性に対する稜の寸法比の影響に 3い, 京都大学防災研究所年報第 23 号 B 1, 1980,pp. 241-255.

4) Bishop, R.E.D. and A.Y.Hassan : The lift and drag forces on a circular cylinder oscillating in a flowing fluid, Proc.Roy. Soc. A, Vol.277,1964,pp.51-75.

5）鉒口展宏・田中博喜・高原茂・松井友二：振 動円柱の非定常空気力几関する研究，構造物の 耐風性儿関する第 1 回シンポ, $1970, \mathrm{pp} .153$ -159 .

6) Yano, T. and S. Takahara : Study on unsteady aerodynamic forces acting on an oscillating cylinder, Proc.3rd Int.Cont. on Wind Effects on Buildings and Structures (Tokyo), 1971,Paper IV-10.

7) 田中宏・伊藤学：充腹構造物の自励振動に打 ける空気力の特性, 土木学会論文報告集, 第168号，1969,pp.15-24.

8）伊藤学・宮田利雄・森光康夫：正方形柱に作 用する装動抗揚力，構造物の耐風性儿関する第 2 回シンポ, $1972, \mathrm{pp}$.159-165. 
9）森光康夫：非定常架気力の非線形についての 考察, 同上, $\mathrm{pp}$.183-190.

10）森光康夫 - 伊藤学・宮田利雄：空気力の非線 形性を考虑した構造物の空力弾性振動, 土木学 会論文報告集，第 219 号，1974，pp 209-214. 11）满田武人・中村泰治：矩形断面柱の非定常揚 力と後流の速度変動几ついて, 構造物の耐風性 几関する第 3 回シンポ, $1974, \mathrm{pp}$.209-214. 12) Nakamura $Y$. and T. Mizota: Unsteady lifts and wakes of oscillating rectangular prisms,. Proc. ASCE, Vol.101, EM6,Dec., $1975, \mathrm{pp} .855-871$.

13) Otsuki, Y., K. Washizu, H.Tomizawa and $\mathrm{A}$. Ohya : $\mathrm{A}$ note on the aeroelastic instability of a prismatic bar with square section, Jour. Sound and Vibration, Vol.34,1974,pp.233-248.

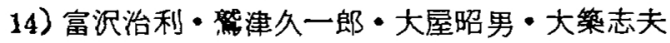
: 箱型模型の風洞実験 (第 2 報), 清水建設研 究所報, 第 20 号, $1973, \mathrm{pp} .39-58$.

15）石崎潑雄・谷池義人・近藤宏二：角柱振動時 の風圧力特性について(その 1$)$, 京都大学防 災研究所年報, 第 24 号 B $-1,1981$, pp. 279-305.

16) Parkinson, G.V.: Wind-induced instability of structures, Phil.Trans. Roy.Soc., A 269,1971,pp.395-409.

17) Tanida, Y., A. Okajima and Y. Watanabe : Stability of a circular cylinder oscillating in uniform flow in a wake, Jour. Fluid Mech., Vol.61, Part 4, 1973 , pp. 769-784.

18) Hartlen, R.T . and I .G. Currie: Liftoscillator model of vortex-induced vibration, Proc, ASCE. Vol.96,EM5 ,Oct., 1970, pp. 577-591.

19) 中村泰治：構造物のうず励振と同期現象につ いて，構造物の耐風性に関する第 3 回シンポ， $1974, \mathrm{pp} .209-214$.

20) Scruton, C.: On the wind-excited oscillations of stacks, towers and masts, Proc. Int. Conf. on Wind Effects on Buildings and Structures(Teddington), $1963, \mathrm{pp} .797$ -836 .

21) Stoker, J . Non-linear vibrations, Interscience Publishers, 1950 .

22）石崎潑雄・谷池義人：3 次元角柱のギャロッ ピングに対するアスペクト比の影響について, 日本建築学会論文報告集, 第 292 号, 1980 , pp. 11-22.

23）石崎潑雄 - 谷池義人：風向直角方向に振動す る角柱の空力不安定性について (正・続)，同 上，第306,307号, 1981 。 